\title{
An Improved High-performance Liquid Chromatographic Method for the Determination of Soluble Sugars in Root Exudates of Greenhouse Cucumber Grown under $\mathrm{CO}_{2}$ Enrichment
}

\begin{abstract}
Xun Li
State Key Laboratory of Soil and Sustainable Agriculture, Institute of Soil Science, Chinese Academy of Sciences, Nanjing, 210008, China

Wenying Chu and Jinlong Dong

State Key Laboratory of Soil and Sustainable Agriculture, Institute of Soil Science, Chinese Academy of Sciences, Nanjing, 210008, China; and University of Chinese Academy of Sciences, Beijing, 100049, China

Zengqiang Duan ${ }^{1}$

State Key Laboratory of Soil and Sustainable Agriculture, Institute of Soil Science, Chinese Academy of Sciences, Nanjing, 210008, China

AdDitional IndeX words. Cucumis sativus, dry weight, growth stage, invertase, net photosynthesis rate, sugar composition

Abstract. This study described a simple and quick method to detect trace quantities of a non-reducing sugar (viz. sucrose) in the root exudates of cucumber (Cucumis sativus) under $\mathrm{CO}_{2}$ enrichment. Sucrose was determined by analyzing fructose and glucose before and after invertase digestion using high-performance liquid chromatography. Using this technique, the optimal hydrolysis condition was $5.00 \mu \mathrm{g} \cdot \mathrm{mL}^{-1}$ invertase for 10 minutes. The detection limit of ultraviolet-visible detector by post-column derivatization with tetrazolium was $0.25,0.43,0.48$, and $1.95 \mu \mathrm{g} \cdot \mathrm{mL}^{-1}$ for fructose, glucose, sucrose, and maltose, respectively, and sensitive enough for determination of sugars in root exudates. The dry weight of cucumber at the seedling stage (19 days after transplant) increased by $58.4 \%$ when the $\mathrm{CO}_{2}$ level was elevated from 380 to $1200 \mu \mathrm{mol} \cdot \mathrm{mol}^{-1}$, whereas the differences were not significant at the initial fruiting stage (63 days after transplant). The photosynthesis rate in $1200 \mu \mathrm{mol} \cdot \mathrm{mol}^{-1} \mathrm{CO}_{2}$ was $58.0 \%$ higher than that in $380 \mu \mathrm{mol} \cdot \mathrm{mol}^{-1} \mathrm{CO}_{2}$ at the seedling stage and 74.2\% higher at the initial fruiting stage. Total amount of sugars in cucumber root exudates was significantly increased with increasing $\mathrm{CO}_{2}$ concentration. The total sugars in root exudates increased by $130.4 \%$ and $102.3 \%$ in $1200 \mu \mathrm{mol} \cdot \mathrm{mol}^{-1} \mathrm{CO}_{2} \mathrm{compared}$ with that in $380 \mu \mathrm{mol} \cdot \mathrm{mol}^{-1} \mathrm{CO}_{2}$ at seedling and initial fruiting stages, respectively. Elevated $\mathrm{CO}_{2}$ altered sugar composition in root exudates. Sugars in root exudates released per plant were significantly higher at the initial fruiting stage than that at the seedling stage, whereas the differences in sugars released per gram of root tissue between these two growth stages were not significant. Our results suggest that sugars were increased only in as much as root mass increased. This study provides a simple and quick method to detect 1 to $500 \mu \mathrm{g} \cdot \mathrm{mL}^{-1}$ sugars in root exudates, and the results illustrate the variation in the sugar composition in cucumber root exudates among the $\mathrm{CO}_{2}$ levels and growth stages.
\end{abstract}

In China, greenhouses are often not ventilated during cold winter months until midday when greenhouse temperature reaches the optimal value for plant growth. Therefore, at midday, the $\mathrm{CO}_{2}$ concentration in greenhouses will drop to very low levels, which may result in inhibition of plants photosynthesis (Kläring et al., 2007). For this reason, $\mathrm{CO}_{2}$ concentration inside the greenhouse usually is increased by adding $\mathrm{CO}_{2}$ gas (Mortensen, 1987). $\mathrm{CO}_{2}$ enrichment not only has a dramatic effect on above-ground plant growth and physiology by changing the photosynthetic assimilation rates, but also affects below-ground processes by altering the quantity and composition of root exudates (Berntson and Bazzaz, 1996; Cardon, 1996). Root exudates, which comprise $15 \%$ to $25 \%$ of

Received for publication 19 Dec. 2013. Accepted for publication 20 Feb. 2014. We thank the National Natural Science Foundation of China (No.41101272) and National Science and Technology Support Program of China (2014BAD14B04) for funding support.

${ }^{1}$ Corresponding author. E-mail: zqduan@issas.ac.cn. below-ground allocated carbon, include sugars, organic acids, amino acids, secondary metabolites, peptides, proteins, and lipids (Kuzyakov, 2002). Among them, sugars are the most abundant and serve as a direct energy source for most of the microorganisms in the rhizosphere (Curl and Truelove, 1986; Schönwitz and Ziegler, 1982). Consequently, it is essential to understand the effects of $\mathrm{CO}_{2}$ enrichment on sugars in root exudates, which are released to the rhizosphere.

Because identification and quantification of individual and trace amounts of sugars pose several analytic problems, most research only determined the total content of sugars in the root exudates by using anthrone's method (Heim et al., 2000; Kato et al., 1997). Owing to the low volatility of sugars, some tedious derivatization steps such as silylation (Sweeley et al., 1963), acetylation (Albersheim et al., 1968), and methylation (Hanisch, 1994) are usually involved before gas chromatography-mass spectrometry analysis. As a result of the high specificity of each enzyme, the enzymatic assays developed recently can be only used for a few common sugars such as sucrose, glucose, and fructose 
(Spackman and Cobb, 2002). Therefore, high-performance liquid chromatography (HPLC) is considered as a powerful and widely used technique for quantifying various types of sugar mixtures (Montero et al., 2004).

Many chemical derivatization methods have been developed for detection of sugar mixtures. However, most chromogenic or fluorescent agents like tetrazolium blue (D'Amboise et al., 1980) and benzamidine (Kai et al., 1985) have weak responses to non-reducing sugars, which are abundant in root exudates. So, in many previous studies, only the reducing sugars in root exudates were reported (Kravchenko et al., 2003; Tawaraya et al., 1994), or sucrose was measured by another method (Lugtenberg et al., 1999). Although arginine (Mikami and Ishida, 1983) and periodic acid with guanidine hydrochloride (Masuda et al., 1996) have been reported for the derivatization of sucrose, much lower activity $(10 \%$ activity of reducing sugars), long separation time (more than $1 \mathrm{~h}$ ), high reaction temperature (near $150{ }^{\circ} \mathrm{C}$ ), and ultra-long tubing system (as long as $24 \mathrm{~m}$ ) limit their use for root exudate analysis. Therefore, a simple, quick method to detect trace quantities of sucrose with high sensitivity and selectivity is urgently needed.

Invertase is an enzyme that hydrolyzes sucrose into fructose and glucose with high efficiency in mild conditions (Nelson and Schubert, 1928). So, it is reasonable to determine sucrose by analyzing fructose and glucose before and after invertase digestion by a regular HPLC process. The objectives of this study were 1) to find the optimal reaction conditions for hydrolysis of sucrose by invertase; 2) to identify the soluble sugars in root exudates by HPLC; and 3) to investigate the amounts and components of soluble sugar in cucumber root exudates under different $\mathrm{CO}_{2}$ concentrations at different growth stages.

\section{Materials and Methods}

Hydrolysis of sucrose by invertase. Time-dependent experiments were carried out to trace the hydrolysis process of sucrose. Invertase (invertase from baker's yeast, Grade VII, $300 \mathrm{U} \cdot \mathrm{mg}^{-1}$ or greater solid; Sigma-Aldrich St. Louis, MO) solution $\left(1000 \mu \mathrm{g} \cdot \mathrm{mL}^{-1}\right)$ was prepared with ultrapure water. Sucrose solutions $\left(10.0 \mathrm{~mL}, 500 \mu \mathrm{g} \cdot \mathrm{mL}^{-1}\right)$ were kept at $50^{\circ} \mathrm{C}$ in a water bath, and enzymatic hydrolysis was started by adding a specific volume of invertase solution to obtain final invertase concentrations of 5.00, 1.00, 0.10, and $0.01 \mu \mathrm{g} \cdot \mathrm{mL}^{-1}$. After 5, 10,30 , and $60 \mathrm{~min}$, the reaction was stopped by immersing the mixed solution in a boiling water bath for $10 \mathrm{~min}$. Fructose and glucose in the final solutions were analyzed by HPLC.

Growing Conditions. The experiment was carried out in the glasshouse at Institute of Soil Science, Chinese Academy of Sciences, Nanjing, P.R. China, from Nov. 2012 to Jan. 2013. Seeds of cucumber (cv. Jinlv 3) were germinated on moist filter paper in a growth chamber at a temperature of $28{ }^{\circ} \mathrm{C}$ and a relative humidity of $70 \%$. Two days later, the seeds with radicles were sown into trays containing a peat-vermiculite mixture $(2: 1, \mathrm{v} / \mathrm{v})$. When two true leaves were fully expanded, seedlings were transplanted to elaborate polyvinyl chloride polymer pots $(5 \mathrm{~L})$, which contain $4 \mathrm{~L}$ of Yamazaki nutrient solution for cucumber (Yamazaki, 1982) with two plants per pot on 16 Nov. 2012. The nutrient solution was composed of $826 \mathrm{mg} \cdot \mathrm{L}^{-1} \mathrm{Ca}\left(\mathrm{NO}_{3}\right)_{2} \cdot 4 \quad \mathrm{H}_{2} \mathrm{O}, 115 \mathrm{mg} \cdot \mathrm{L}^{-1} \mathrm{NH}_{4} \mathrm{H}_{2} \mathrm{PO}_{4}, 607$ $\mathrm{mg} \cdot \mathrm{L}^{-1} \mathrm{KNO}_{3}, 493 \mathrm{mg} \cdot \mathrm{L}^{-1} \mathrm{MgSO}_{4} \cdot 7 \quad \mathrm{H}_{2} \mathrm{O}, 29.27 \mathrm{mg} \cdot \mathrm{L}^{-1}$
$\mathrm{Na}_{2} \mathrm{Fe}-E D T A, 2.86 \mathrm{mg} \cdot \mathrm{L}^{-1} \mathrm{H}_{3} \mathrm{BO}_{3}, 2.03 \mathrm{mg} \cdot \mathrm{L}^{-1} \mathrm{MnSO}_{4} \cdot 4$ $\mathrm{H}_{2} \mathrm{O}, 0.22 \mathrm{mg} \cdot \mathrm{L}^{-1} \mathrm{ZnSO}_{4} \cdot 7 \mathrm{H}_{2} \mathrm{O}, 0.08 \mathrm{mg} \cdot \mathrm{L}^{-1} \mathrm{CuSO}_{4} \cdot 5 \mathrm{H}_{2} \mathrm{O}$, and $0.02 \mathrm{mg} \cdot \mathrm{L}^{-1}\left(\mathrm{NH}_{4}\right)_{6} \mathrm{Mo}_{7} \mathrm{O}_{24} \cdot 4 \mathrm{H}_{2} \mathrm{O}$. The $\mathrm{pH}$ was adjusted to 6.5 using diluted $\mathrm{KOH}$ and $\mathrm{H}_{2} \mathrm{SO}_{4}$. The solution was aerated intermittently for 30 min every hour and renewed completely every $4 \mathrm{~d}$. When the plant had five to six true leaves, one plant in each pot was harvested for analysis on 5 Dec. 2012. When small fruit of 5 to $8 \mathrm{~cm}$ long formed, the plant left in each pot was harvested on 18 Jan. 2013. Six pots of replications (12 plants of replications at seedling stage and six replications at initial fruiting stage) were grown within open-top chambers [OTC $(2.3 \mathrm{~m}$ length $\times 0.8 \mathrm{~m}$ width $\times 1.4 \mathrm{~m}$ height $)]$ under natural light. The $\mathrm{CO}_{2}$ concentration in three identical OTCs was set as 380, 625 , and $1200 \mu \mathrm{mol} \cdot \mathrm{mol}^{-1}$, respectively, and was continuously monitored and controlled through an infrared gas analyzer (Ultramat 6; Siemens, Munich, Germany) from 0800 to $1700 \mathrm{HR}$ everyday. The temperature and relative humidity within the OTCs were recorded by a L95-83 recorder (Hangzhou Loggertech Co., Hangzhou, China) every $10 \mathrm{~min}$. The temperature and relative humidity during the experiment range from 12 to $30^{\circ} \mathrm{C}$ and $30 \%$ to $80 \%$, respectively.

Collection and fractionation of root exudates. The root exudates of cucumber were collected at seedling (4 Dec. 2012) and initial fruiting stages (17 Jan. 2013) by a modified continuous trapping system similar to that designed by Tang and Young (1982) (Fig. 1). The nutrient solution in each pot was simultaneously driven and continuously recycled at the rate of $25 \mathrm{~mL} \cdot \mathrm{min}^{-1}$ by a peristaltic pump (BT100-1L; Baoding Longer Precision Pump Co., Baoding, China) from 0900 to $1500 \mathrm{HR}$ on the day after the nutrient solution was renewed. The trapping column was packed with $20 \mathrm{~cm}^{3}$ of resin (Amberlite XAD-4; Alfa Aesar, Ward Hill, MA) and filled with cotton on both sides. All the tubes and the column were covered with aluminum foil completely to avoid algal growth. After collection, the column was taken off to drain off excess nutrient solution, and then the resin was washed with $100 \mathrm{~mL}$ of ethanol. The ethanol was removed using a vacuum rotary evaporator at $40{ }^{\circ} \mathrm{C}$ and the residue was redissolved in $10 \mathrm{~mL}$ ultrapure water. Root exudates in the aqueous solution were separated by ion exchange resins (Gransee and Wittenmayer, 2000). The aqueous solution was first passed through a cation exchange column

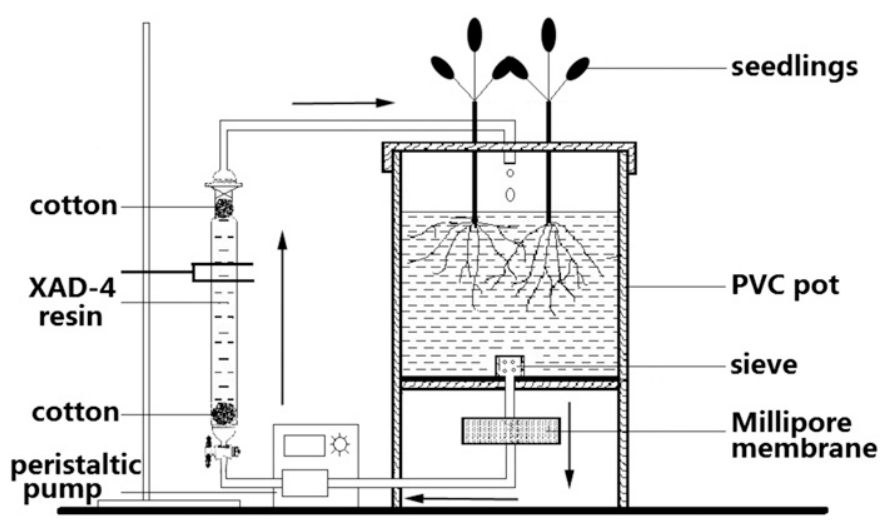

Fig. 1. Schematic illustration of the continuous trapping system for collecting the root exudates of cucumber. The nutrient solution in the polyvinyl chloride polymer pot was driven by a peristaltic pump and flow-through sieve, Millipore membrane (Merck Millipore, Billerica, MA) and XAD-4 resin (Alfa Aesar, Ward Hill, MA) and then back to the pot. 
(Amberlite IR-120, $\mathrm{H}^{+}$form, column bed $20 \mathrm{~cm}^{3}$; Alfa Aesar), and the effluent was then passed through an anion exchange column (Amberlite IRA-410, formate form, column bed $20 \mathrm{~cm}^{3}$; Alfa Aesar). The final effluent was lyophilized and the residue was redissolved in $4 \mathrm{~mL}$ ultrapure water, $2 \mathrm{~mL}$ of which was hydrolyzed by $5 \mu \mathrm{g} \cdot \mathrm{mL}^{-1}$ invertase for $10 \mathrm{~min}$. Sugars in the root exudates solution before and after hydrolysis were determined by HPLC.

Chromatographic conditions. HPLC analysis was performed on a LC-10AVP HPLC system (Shimadzu, Kyoto, Japan) equipped with LC-10ATVP pump, SPD-10AVP ultravioletvisible detector, CTO-10AVP column oven, CRB-6A chemical reaction box, SIL-10AVP autosampler, and Shimadzu LC solution software (Class-VP Version 6.1). Samples were filtered through 0.20- $\mu \mathrm{m}$ Millipore membrane (Merck Millipore, Billerica, MA) and $10 \mu \mathrm{L}$ filtrate was injected for analysis. Separation of sugars was achieved on a Shim-pack CLC-NH $\mathrm{N}_{2}(\mathrm{M})$ column (250 mm length $\times 4.6 \mathrm{~mm}$ diameter; Shimadzu) maintained at $25{ }^{\circ} \mathrm{C}$ by elution with acetonitrile-water $(75: 25 \mathrm{v} / \mathrm{v}$, HPLC-grade acetonitrile; Sigma-Aldrich) at a flow rate of $1.0 \mathrm{~mL} \cdot \mathrm{min}^{-1}$ (Lugtenberg et al., 1999). After separation, the eluate was mixed through a $\mathrm{T}$-joint with tetrazolium reagent. The reagent was composed of $2 \mathrm{~g} \cdot \mathrm{L}^{-1}$ blue tetrazolium chloride (Alfa Aesar) in $7.2 \mathrm{~g} \cdot \mathrm{L}^{-1} \mathrm{NaOH}$ and pumped at $0.2 \mathrm{~mL} \cdot \mathrm{min}^{-1}$. The derivatization was conducted at $85{ }^{\circ} \mathrm{C}$ through a stainless steel tube $(3 \mathrm{~m}$ length $\times 0.25 \mathrm{~mm}$ i.d.) in the chemical reaction box. Derivatizated mixtures were cooled by passing through a stainless steel tube $(1 \mathrm{~m}$ length $\times 0.25 \mathrm{~mm}$ i.d. $)$ in an ice-water bath; the sugars were detected at $487 \mathrm{~nm}$ using the ultravioletvisible detector. Sugars were identified by comparing the retention times of sample peaks with standards.

Dry Weight AND PHOtosynthetiC RATe anAlysis. Plants were separated into roots, stems, and leaves after the whole plants were removed from the pots. Dry weight (DW) of each organ was determined by drying the fresh tissues at $105^{\circ} \mathrm{C}$ for $30 \mathrm{~min}$ and then further drying at $80^{\circ} \mathrm{C}$ for $24 \mathrm{~h}$. Photosynthetic rate (Pn) was measured on clear days (3 Dec. 2012 at the seedling stage and 10 Jan. 2013 at the initial fruiting stage) from 0900 to $1500 \mathrm{HR}$ using a portable photosynthetic apparatus (LI-6400; LI-COR, Lincoln, NE) equipped with a standard leaf chamber. Twelve leaves (the fourth leaf from the apex on each plant at the seedling stage; the fourth and fifth leaves on each plant at the initial fruiting stages) from each treatment were measured. The photosynthetic photon flux density was set as $1500 \mu \mathrm{mol} \cdot \mathrm{m}^{-2} \cdot \mathrm{s}^{-1}$, which was provided by an attached LI-6400-02B blue-red light-emitting diode light. Temperature of the air in the leaf chamber was set to $25{ }^{\circ} \mathrm{C}$ and the $\mathrm{CO}_{2}$ concentration in the leaf chamber was set the same as the $\mathrm{CO}_{2}$ environment where the plants were grown.

Statistical analysis. Time-dependent experiments of sucrose hydrolysis were replicated five times. DW of each plant and sugar composition of root exudates were analyzed as a three $\times$ two factorial $\left(\mathrm{CO}_{2}\right.$ concentration $\times$ growth stage $)$ using a completely randomized block design with six replications. Pn was measured on 12 leaves from 12 individual plants at the seedling stage and from six individual plants at the initial fruiting stage for each treatment. Ten readings were recorded from each leaf and averaged as one observation. Pn data presented are means of 12 observations. Statistical analysis was performed using SPSS software (Version 18.0; IBM Corp., Armonk, NY). Differences between means under the same $\mathrm{CO}_{2}$ concentration at two different growth stages were evaluated by independent samples $t$ test. Differences among means under different $\mathrm{CO}_{2}$ concentrations at the same growth stage were separated using Duncan tests of one-way analyses of variance at $P \leq 0.05$. Error was reported as the SEM. Figures and linear fitting procedures were generated by OriginPro (Version 8.0; OriginLab Corp., Northampton, MA).

\section{Results}

SeParation of STANDARd SUgar mixture. A typical chromatogram of a mixture of three standard sugars (each was 250 $\mu \mathrm{g} \cdot \mathrm{mL}^{-1}$ ) separated by HPLC was shown in Figure 2 , in which fructose, glucose, and maltose were eluted at 9.404, 10.598, and $17.049 \mathrm{~min}$, respectively. All the peaks were symmetrical and the total separation time was no more than 20 min. A linear response was obtained with fructose, glucose, and maltose up to $500 \mu \mathrm{g} \cdot \mathrm{mL}^{-1}$, and the detection limit was $0.25,0.43$, and 1.95 $\mu \mathrm{g} \cdot \mathrm{mL}^{-1}$ (signal $/$ noise $=3$ ). $R^{2}$ values of the corresponding fitted lines were $0.996,0.999$, and 0.997, respectively. Sucrose cannot form chromatic derivatives directly with blue tetrazolium, whereas fructose and glucose, which were the hydrolysates of sucrose, can be colored. An equal amount of fructose and glucose was detected in the sucrose solutions after hydrolysis by invertase. Because the sensitivity of fructose was higher than that of glucose, the fructose contribution to sucrose was used to calculate the initial concentration of sucrose. The linear response of sucrose was up to $1000 \mu \mathrm{g} \cdot \mathrm{mL}^{-1}$, and the detection limit was $0.48 \mu \mathrm{g} \cdot \mathrm{mL}^{-1}$.

CONDition of SuCrose hydrolysis. Hydrolysis of sucrose by invertase was traced by time-dependent experiments (Fig. 3).

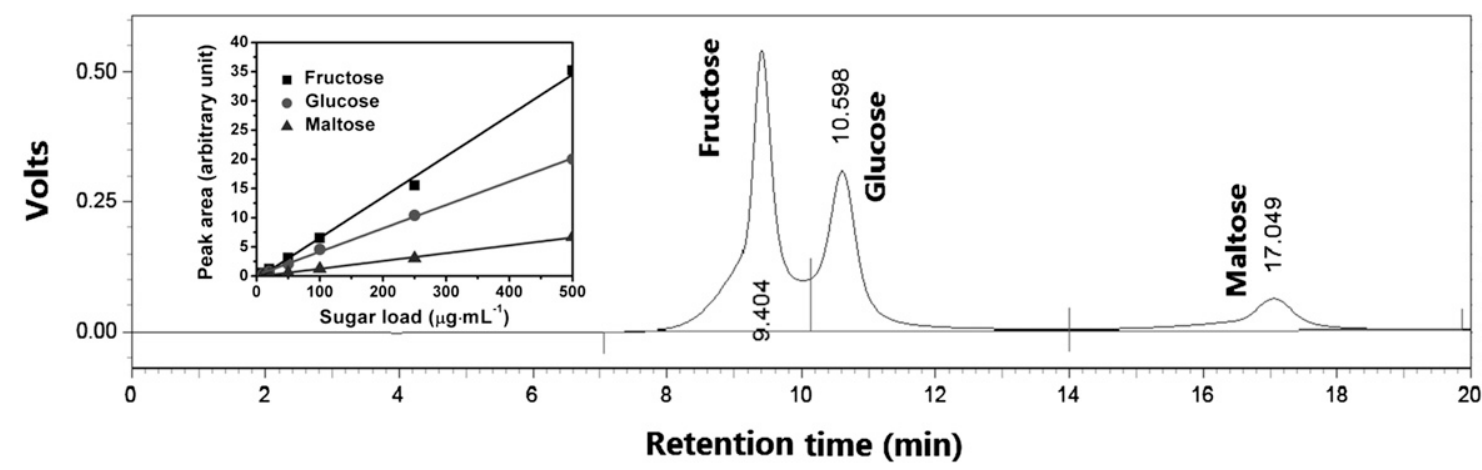

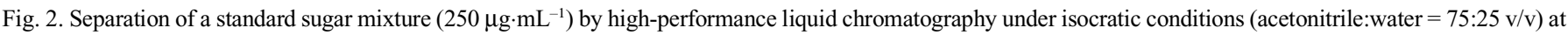
a flow rate of $1.0 \mathrm{~mL} \cdot \mathrm{min}^{-1}$ at $25^{\circ} \mathrm{C}$ (inset = calibration plot). 
It can be seen that the rate of sucrose hydrolysis increased with increasing invertase concentration. Completed hydrolysis was achieved at 5, 10, and $30 \mathrm{~min}$ when $5.00,1.00$, and $0.10 \mu \mathrm{g} \cdot \mathrm{mL}^{-1}$ invertase was used, respectively. When $0.01 \mu \mathrm{g} \cdot \mathrm{mL}^{-1}$ invertase was used, only $20 \%$ to $30 \%$ sucrose was hydrolyzed when the reaction time lasted $60 \mathrm{~min}$. To ensure the completed hydrolysis of sucrose, all the samples in sucrose detection were hydrolyzed in $5 \mu \mathrm{g} \cdot \mathrm{mL}^{-1}$ invertase for $10 \mathrm{~min}$.

EFFECT OF THE ATMOSPHERIC $\mathrm{CO}_{2}$ CONCENTRATION ON PLANT GROWTH AND PHOTOSYNTHETIC RATE. The DW of roots, stems, and leaves of cucumber was altered by $\mathrm{CO}_{2}$ concentrations (Table 1). At the seedling stage (19 d after transplant), DW of roots, stems, and leaves of the plant grown under $1200 \mu \mathrm{mol} \cdot \mathrm{mol}^{-1} \mathrm{CO}_{2}$ was significantly greater than that under $380 \mu \mathrm{mol} \cdot \mathrm{mol}^{-1} \mathrm{CO}_{2}$. At the initial fruiting stage (63 d after transplant), the greatest root and stem DW were also obtained under $1200 \mu \mathrm{mol} \cdot \mathrm{mol}^{-1} \mathrm{CO}_{2}$, but the differences of leaf and whole plant DW among treatments were not significant. DWs of plant tissues and the whole plant under 380 and $625 \mu \mathrm{mol} \cdot \mathrm{mol}^{-1} \mathrm{CO}_{2}$ were similar at seedling and initial fruiting stages, except stem at the seedling stage. The root/shoot was not significantly affected by $\mathrm{CO}_{2}$ concentration or growth stage.

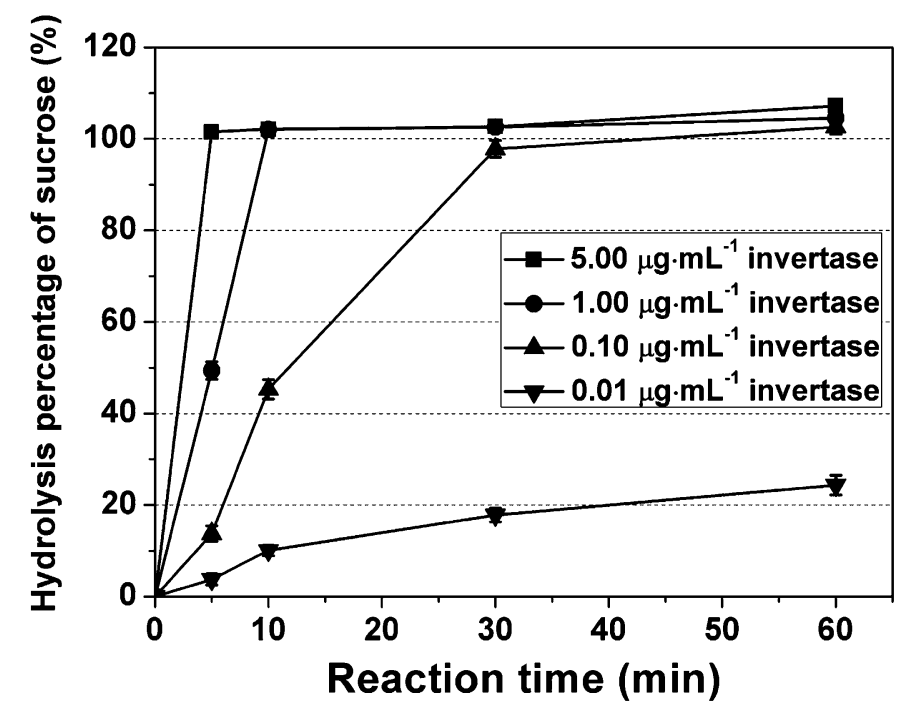

Fig. 3. Extent of standard sucrose $\left(500 \mu \mathrm{g} \cdot \mathrm{mL}^{-1}\right)$ hydrolysis as a function of time with different invertase concentrations. Data are means \pm SE $(n=5)$.

Table 1. Dry weight of roots, stems, leaves, and the whole plants of cucumber under different $\mathrm{CO}_{2}$ concentrations at seedling and initial fruiting stages $(n=6)$.

\begin{tabular}{llccc}
\hline & & \multicolumn{3}{c}{ Dry wt $[\mathrm{mean} \pm \mathrm{SE}(\mathrm{mg} / \mathrm{plant})]$} \\
\cline { 3 - 5 } Stage & Plant tissue & $380 \mu \mathrm{mol} \cdot \mathrm{mol}^{-1} \mathrm{CO}_{2}$ & $625 \mu \mathrm{mol} \cdot \mathrm{mol}^{-1} \mathrm{CO}_{2}$ & $1200 \mu \mathrm{mol} \cdot \mathrm{mol}^{-1} \mathrm{CO}_{2}$ \\
\hline Seedling & Roots & $70.2 \pm 4.8 \mathrm{~b}^{\mathrm{z}}$ & $88.2 \pm 5.4 \mathrm{~b}$ & $121.7 \pm 14.8 \mathrm{a}$ \\
stage & Stems & $157.7 \pm 10.3 \mathrm{~b}$ & $227.1 \pm 23.0 \mathrm{a}$ & $281.1 \pm 23.6 \mathrm{a}$ \\
& Leaves & $638.8 \pm 27.3 \mathrm{~b}$ & $748.6 \pm 33.2 \mathrm{~b}$ & $969.7 \pm 58.4 \mathrm{a}$ \\
\multirow{2}{*}{ Initial fruiting } & Total & $866.6 \pm 37.1 \mathrm{~b}$ & $1064.0 \pm 60.0 \mathrm{~b}$ & $1372.6 \pm 93.6 \mathrm{a}$ \\
stage & Root/shoot & $0.0890 \pm 0.0074 \mathrm{a}$ & $0.0906 \pm 0.0031 \mathrm{a}$ & $0.0957 \pm 0.0032 \mathrm{a}$ \\
& Roots & $606.8 \pm 75.6 \mathrm{~b}$ & $623.0 \pm 86.6 \mathrm{~b}$ & $923.8 \pm 109.4 \mathrm{a}$ \\
& Stems & $2121.4 \pm 154.1 \mathrm{~b}$ & $2192.2 \pm 248.1 \mathrm{ab}$ & $3092.2 \pm 442.8 \mathrm{a}$ \\
& Leaves & $3863.8 \pm 381.2 \mathrm{a}$ & $4235.4 \pm 697.4 \mathrm{a}$ & $5485.1 \pm 789.3 \mathrm{a}$ \\
& Total & $6592.0 \pm 589.9 \mathrm{a}$ & $7050.6 \pm 1021.3 \mathrm{a}$ & $9501.1 \pm 1328.4 \mathrm{a}$ \\
& Root/shoot & $0.1007 \pm 0.0063 \mathrm{a}$ & $0.0979 \pm 0.0048 \mathrm{a}$ & $0.1098 \pm 0.0030 \mathrm{a}$ \\
\hline
\end{tabular}

${ }^{\mathrm{z}}$ Means within rows not followed by the same letter are significantly different at $P \leq 0.05$.
Pn values under different $\mathrm{CO}_{2}$ concentrations applied are shown in Figure 4. Pn of the plant grown under $1200 \mu \mathrm{mol} \cdot \mathrm{mol}^{-1}$ $\mathrm{CO}_{2}$ was significantly higher than that under $380 \mu \mathrm{mol} \cdot \mathrm{mol}^{-1}$ $\mathrm{CO}_{2}$ treatment at both seedling and initial fruiting stages. During the growth of cucumber, Pn was decreased from the seedling to initial fruiting stage by $31.7 \%$ to $43.4 \%$ in all three $\mathrm{CO}_{2}$ treatments.

EFFECT OF THE ATMOSPHERIC $\mathrm{CO}_{2}$ CONCENTRATION ON SUGAR COMPONENT IN ROOT EXUDATES. The amounts of four common sugars in the root exudates released by one cucumber plant under different $\mathrm{CO}_{2}$ concentrations are listed in Table 2. Concentrations of sugar from plants growing under $1200 \mu \mathrm{mol} \cdot \mathrm{mol}^{-1} \mathrm{CO}_{2}$ were greater than that under $380 \mu \mathrm{mol} \cdot \mathrm{mol}^{-1} \mathrm{CO}_{2}$. At the seedling stage, fructose and glucose in the root exudates increased when the concentration of $\mathrm{CO}_{2}$ was elevated to 625 $\mu \mathrm{mol} \cdot \mathrm{mol}^{-1}$, whereas concentrations of other sugars released under 380 and $625 \mu \mathrm{mol} \cdot \mathrm{mol}^{-1} \mathrm{CO}_{2}$ were similar. At the initial fruiting stage, only glucose concentration under $625 \mu \mathrm{mol} \cdot \mathrm{mol}^{-1}$ $\mathrm{CO}_{2}$ was greater than that under $380 \mu \mathrm{mol} \cdot \mathrm{mol}^{-1} \mathrm{CO}_{2}$. Glucose was the major sugar in root exudates and constituted $\approx 40 \%$ of the total pool of sugars, and fructose was the second major sugar, which constituted $\approx 25 \%$ of the total sugars (Table 3 ). Two disaccharides, sucrose and maltose, were less than $20 \%$ of the total sugars. As plants grew, the total amount of sugars was increased almost 5-fold from seedling to initial fruiting stage.

The $\mathrm{CO}_{2}$ concentration altered the specific root exudation of sugars per gram DW of root tissue (Fig. 5). Cucumber seedlings growing under $1200 \mu \mathrm{mol} \cdot \mathrm{mol}^{-1} \mathrm{CO}_{2}$ released more fructose and glucose in root exudates per gram DW than under 380 $\mu \mathrm{mol} \cdot \mathrm{mol}^{-1} \mathrm{CO}_{2}$. In general, $\mathrm{CO}_{2}$ concentration had little influence on the specific root exudation of sucrose, maltose, and total sugar. At initial fruiting, only the amount of sucrose released per gram DW was increased as the concentration of $\mathrm{CO}_{2}$ increased from 380 to $1200 \mu \mathrm{mol} \cdot \mathrm{mol}^{-1}$. Although the total amount of sugars released per plant was 5-fold higher at the initial fruiting stage than that at the seedling stage (Table 2), it is noteworthy that almost all the sugars released per gram of root tissue were similar between seedling and initial fruiting stages.

\section{Discussion}

Early work reported that yeast invertase was a highly effective catalyst for the hydrolysis of sucrose, and the inversion rate is proportional to the concentration of sucrose, water, and invertase at certain temperatures (Nelson and Schubert, 1928). Therefore, when the concentration of sucrose is constant and very low $\left(500 \mu \mathrm{g} \cdot \mathrm{mL}^{-1}\right)$, the rate of inversion is only determined by the concentration of invertase. In the present study, the rate of sucrose hydrolysis increased with invertase concentration increasing from 0.01 to $5.00 \mu \mathrm{g} \cdot \mathrm{mL}^{-1}$. To make sure that the hydrolysis of sucrose is finished in $10 \mathrm{~min}, 5.00 \mu \mathrm{g} \cdot \mathrm{mL}^{-1}$ invertase is chosen as the optimal dosage.

Refractive index detector (RID) is usually used in quantifying sugar mixtures by HPLC, but its detection limit can be only $100 \mu \mathrm{g} \cdot \mathrm{mL}^{-1}$ for 
fructose, glucose, and sucrose (Sharma et al., 2009). In this work, most sugars collected at the seedling stage in the solution for HPLC analysis were less than $100 \mu \mathrm{g} \cdot \mathrm{mL}^{-1}$, so RID would be unsuitable for detecting the trace quantities of sugars in root exudates. The detection limit of evaporative light-scattering detector (ELSD) has been reported as 44 and $11 \mu \mathrm{g} \cdot \mathrm{mL}^{-1}$ for glucose and sucrose, respectively (Sharma et al., 2010). However, ELSD is not specific for sugars, and other compounds such as organic acids and amino acids in root exudates could interfere with the detection of sugars. Soga et al. (1992) used pulsed amperometric detector (PAD) for the determination of sugars, and the detection limits for fructose, glucose, sucrose, and maltose were $0.09,0.07,0.21$, and $0.27 \mu \mathrm{g} \cdot \mathrm{mL}^{-1}$,

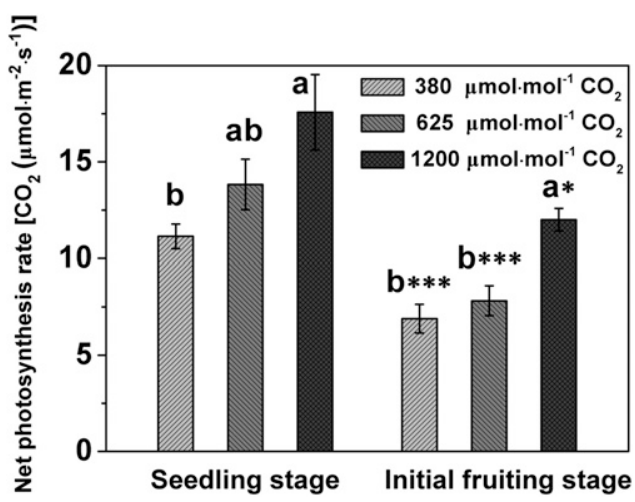

Fig. 4. Effects of $\mathrm{CO}_{2}$ concentration on net photosynthesis rates of cucumber at seedling ( $17 \mathrm{~d}$ after planting) and initial fruiting stages ( $55 \mathrm{~d}$ after planting). Data are means $\pm \operatorname{SE}(n=12)$. Means within the same stage not followed by the same letter are significantly different at $P \leq 0.05$. *,*** Means between different growth stages within each $\mathrm{CO}_{2}$ treatment are significantly different at $P \leq 0.05$ or 0.001 , respectively. respectively (assuming injected volume was $10 \mu \mathrm{L}$ ). However, PAD requires a special stationary phase and tubing system designed for high $\mathrm{pH}$ conditions. The detection limit of the ultraviolet-visible detector in this work was $0.25,0.43,0.48$, and $1.95 \mu \mathrm{g} \cdot \mathrm{mL}^{-1}$ for fructose, glucose, sucrose, and maltose, respectively, which is similar to a previous report (D'Amboise et al., 1980). Therefore, the detection limit of the present method was much better than that of RID and ELSD and was slightly lower than that of PAD. Considering the sugar concentration in root exudates was more than $10 \mu \mathrm{g} \cdot \mathrm{mL}^{-1}$, the present method provides greater economy and adequate sensitivity alternation for determination of sugars in root exudates.

It is well known that $\mathrm{CO}_{2}$ enrichment can increase plant yield and enhance photosynthesis (Kimball, 1983; Makino and Mae, 1999; Peet and Willits, 1987). In cucumber, the plants with $\mathrm{CO}_{2}$ enrichment (700 to $2000 \mu \mathrm{mol} \cdot \mathrm{mol}^{-1}$ ) had $14 \%$ to $259 \%$ more DW and $76 \%$ to $175 \%$ higher Pn than that without $\mathrm{CO}_{2}$ enrichment (Agüera et al., 2006; Sánchez-Guerrero et al., 2005; Segura et al., 2001; Wei et al., 2002). In our study, a 58.4\% increase in DW was observed at the seedling stage when the $\mathrm{CO}_{2}$ level was elevated from 380 to $1200 \mu \mathrm{mol} \cdot \mathrm{mol}^{-1}$ (Table 1). Similarly, the $\mathrm{Pn}$ in $1200 \mu \mathrm{mol} \cdot \mathrm{mol}^{-1} \mathrm{CO}_{2}$ was $58.0 \%$ higher than that in $380 \mu \mathrm{mol} \cdot \mathrm{mol}^{-1} \mathrm{CO}_{2}$ at the seedling stage and $74.2 \%$ higher at the initial fruiting stage, respectively. The unaltered root/shoot means there was no significant difference in dry matter partitioning as a result of $\mathrm{CO}_{2}$ treatment (Hodge et al., 1998). These results were consistent with previous work, and the increased DW and Pn were possibly caused by more fixation of $\mathrm{CO}_{2}$ and accumulation of biomass (Makino and Mae, 1999).

Although the Pn was much larger in plants grown in $1200 \mu \mathrm{mol} \cdot \mathrm{mol}^{-1} \mathrm{CO}_{2}$ than in $380 \mu \mathrm{mol} \cdot \mathrm{mol}^{-1} \mathrm{CO}_{2}$, the difference in DW was not significant at the initial fruiting stage. We found at

Table 2. Sugar composition of cucumber root exudates growing under different $\mathrm{CO}_{2}$ concentrations at seedling and initial fruiting stages $(\mathrm{n}=6)$.

\begin{tabular}{|c|c|c|c|c|}
\hline \multirow[b]{2}{*}{ Stage } & \multirow[b]{2}{*}{ Sugar } & \multicolumn{3}{|c|}{ Sugar $[\text { mean } \pm \mathrm{SE}(\mu \mathrm{g} / \text { plant })]^{\mathrm{z}}$} \\
\hline & & $380 \mu \mathrm{mol} \cdot \mathrm{mol}^{-1} \mathrm{CO}_{2}$ & $625 \mu \mathrm{mol} \cdot \mathrm{mol}^{-1} \mathrm{CO}_{2}$ & $1200 \mu \mathrm{mol} \cdot \mathrm{mol}^{-1} \mathrm{CO}_{2}$ \\
\hline \multirow[t]{4}{*}{ Seedling stage } & Fructose & $199.3 \pm 55.5 \mathrm{~b}^{\mathrm{y}}$ & $388.1 \pm 43.1 \mathrm{a}$ & $525.9 \pm 51.8 \mathrm{a}$ \\
\hline & Glucose & $358.6 \pm 74.3 \mathrm{c}$ & $640.3 \pm 85.0 \mathrm{~b}$ & $926.5 \pm 66.9 \mathrm{a}$ \\
\hline & Maltose & $146.9 \pm 29.1 \mathrm{~b}$ & $210.0 \pm 26.2 \mathrm{ab}$ & $236.0 \pm 18.0 \mathrm{a}$ \\
\hline & Total & $877.6 \pm 184.8 \mathrm{c}$ & $1456.4 \pm 173.3 b$ & $2022.1 \pm 160.8 \mathrm{a}$ \\
\hline \multirow[t]{4}{*}{ Initial fruiting stage } & Fructose & $1854.4 \pm 360.2 \mathrm{~b}$ & $1676.0 \pm 317.0 \mathrm{~b}$ & $2863.6 \pm 238.6 \mathrm{a}$ \\
\hline & Sucrose & $770.3 \pm 108.7 b$ & $1153.9 \pm 159.7 \mathrm{~b}$ & $2583.3 \pm 392.2 \mathrm{a}$ \\
\hline & Maltose & $775.6 \pm 150.9 b$ & $1186.2 \pm 153.4 \mathrm{ab}$ & $1758.0 \pm 299.5 \mathrm{a}$ \\
\hline & Total & $5638.0 \pm 766.4 \mathrm{~b}^{* *}$ & $7428.1 \pm 785.4 \mathrm{~b}^{* * *}$ & $11408.0 \pm 991.2 \mathrm{a}^{* * *}$ \\
\hline
\end{tabular}

${ }^{\mathrm{z}}$ Sugars released by individual plant at the seedling stage were calculated as half the value of the exudates collected from one pot.

${ }^{y}$ Means within rows at the same stage not followed by the same letter are significantly different at $P \leq 0.05$.

**, *** Means between different growth stages within each $\mathrm{CO}_{2}$ treatment are significantly different at $P \leq 0.01$, or 0.001 , respectively (n $=6$ ).

Table 3. Percentage of each sugar in the total amount of four sugars in cucumber root exudates growing under different $\mathrm{CO}_{2}$ concentrations at seedling and initial fruiting stages $(\mathrm{n}=6)$.

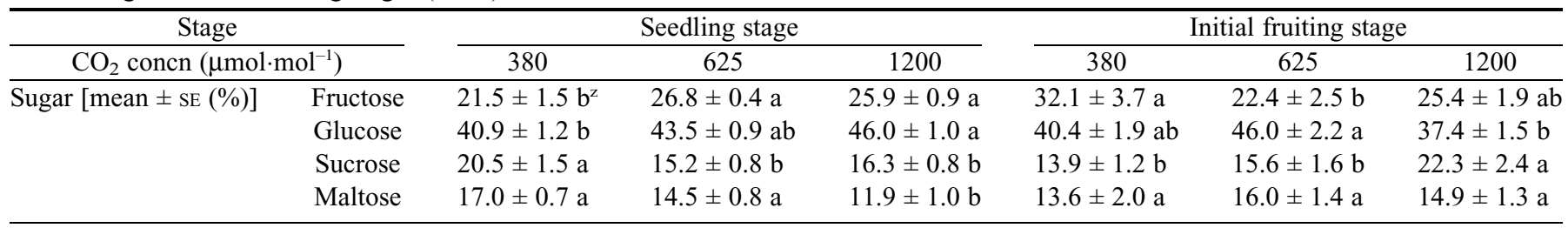

${ }^{\mathrm{z}}$ Means within rows at same stage not followed by the same letter are significantly different at $P \leq 0.05$. 
the end of initial fruiting stage $(\approx 10 \mathrm{~d})$, the daily average temperature in the OTC was less than $18{ }^{\circ} \mathrm{C}$ and the daily minimum temperature was 10 to $12{ }^{\circ} \mathrm{C}$. The effect of $\mathrm{CO}_{2}$ enrichment on biomass may be limited by the low temperature. On the other hand, there were no significant differences in DW and Pn between the cucumber growing in 380 and $625 \mu \mathrm{mol} \cdot \mathrm{mol}^{-1} \mathrm{CO}_{2}$. Because the effect of $\mathrm{CO}_{2}$ enrichment is affected by many factors such as plant species, growth age, temperature, light, nutrients, water, and so on, we speculate that the $\mathrm{CO}_{2}$ concentration that has the largest effect on cucumber is higher than $625 \mu \mathrm{mol} \cdot \mathrm{mol}^{-1}$ in our OTC experiments. It is also noteworthy that the Pn was lower at the initial fruiting stage than that at the seedling stage. This phenomenon has been reported as photosynthetic acclimation and down-regulation of photosynthesis during long-term $\mathrm{CO}_{2}$ enrichment (Ayari et al., 2000; Makino and Mae, 1999).

Sugars are one of the most abundant primary metabolites in root exudates. Vančura and Hovadík (1965) have reported that nine identifiable reducing sugars, viz. arabinose, fructose, glucose, maltose, desoxyribose, xylose, galactose, ribose, and rhamnose, were detected in the root exudates of cucumber seedlings. Changes in the amounts of specific sugars in the root exudates of cucumber have been quantified by Kamilova et al. (2006). They found glucose and fructose were two major sugars in the root exudates of cucumber cultivated on glass beads, which contributed $44.2 \%$ and $40.8 \%$ reducing sugars, respectively, whereas maltose $(11.9 \%)$ and xylose $(3.1 \%)$ were two minor compositions. However, non-reducing sugars were not detected by the method described in their work. We measured similar glucose and fructose concentrations in the root exudates of cucumber as reported by Kamilova et al. (2006). The sugars in the root exudates of cucumber seedlings grown in $380 \mu \mathrm{mol} \cdot \mathrm{mol}^{-1} \mathrm{CO}_{2}$ consisted of glucose $(40.9 \%)$, fructose $(21.5 \%)$, sucrose $(20.5 \%)$, and maltose $(17.0 \%)$. The total amount of sugars released per plant in our study was $\approx 100$ times more than that in Kamilova et al. (2006). Differences in sugar concentrations between our study and those reported by Kamilova et al. (2006) may be a result of different growth conditions, collection methods, and collection durations.

Owing to enhanced Pn and increased plant growth, sugars in root exudates may similarly be expected to increase under $\mathrm{CO}_{2}$ enrichment. Hodge et al. (1998) reported that the free sugars in the root exudates of Lolium perenne were increased under elevated $\mathrm{CO}_{2}$ treatment, whereas the total sugars were decreased. In Haase et al.'s (2007) work, total sugars in the root exudates of Phaseolus vulgaris were increased with $\mathrm{CO}_{2}$ enrichment only in nitrogen $(\mathrm{N})$-deficiency treatments at $12 \mathrm{~d}$ after sowing, whereas they were increased regardless of $\mathrm{N}$ supply at $18 \mathrm{~d}$ after sowing. In our work, total amount of sugars in cucumber root exudates was increased with an increase in $\mathrm{CO}_{2}$ concentration from 380 to $1200 \mu \mathrm{mol} \cdot \mathrm{mol}^{-1}$ at both seedling and initial fruiting stages (Table 2).
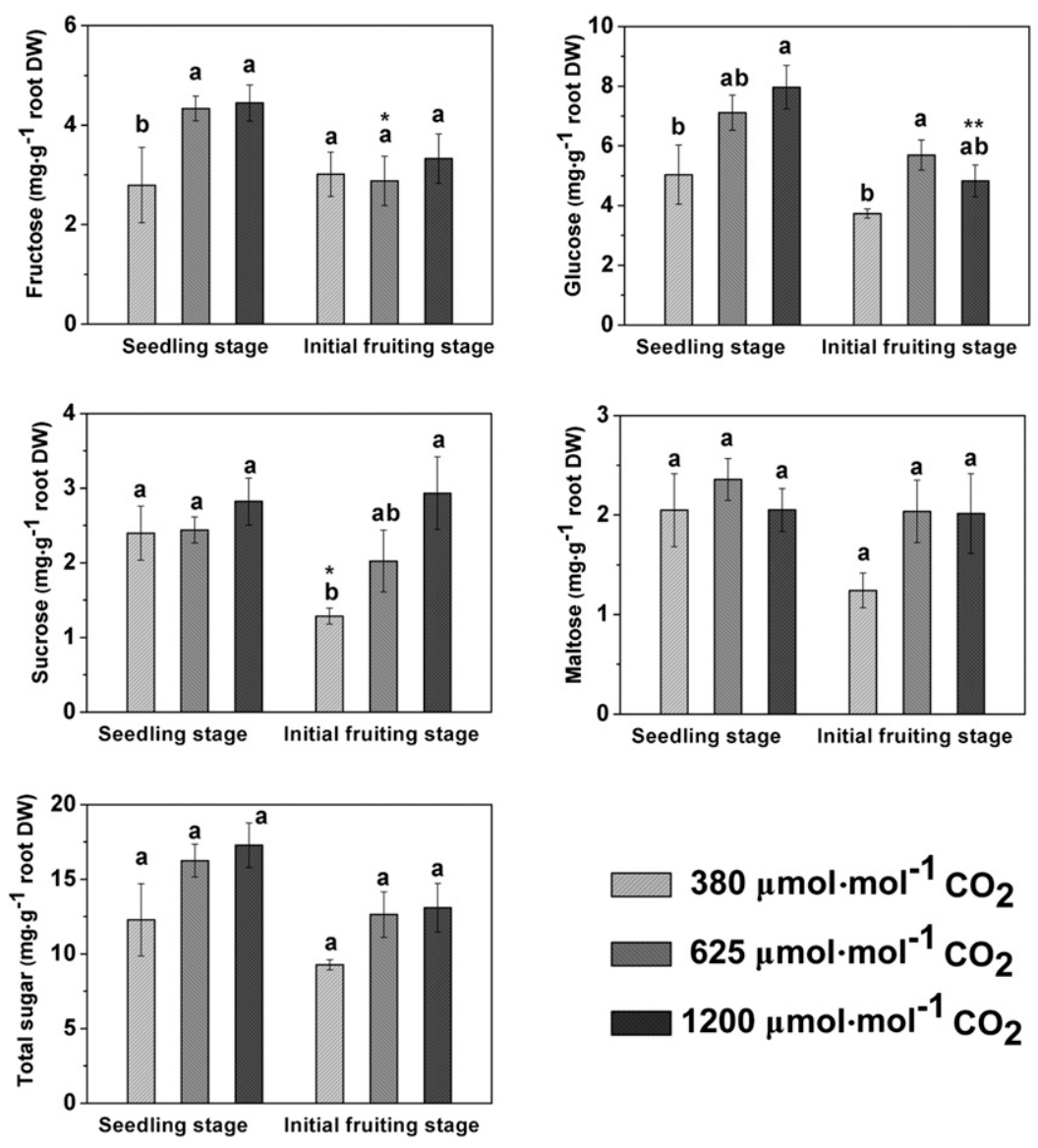

Fig. 5. Sugars released by cucumber roots under different $\mathrm{CO}_{2}$ concentrations at seedling and initial fruiting stages. Data are means $\pm S E(n=6)$. Means within same stage not followed by the same letter are significantly different at $P \leq 0.05(\mathrm{n}=6)$. * ** Means between different growth stages within each $\mathrm{CO}_{2}$ treatment are significantly different at $P \leq 0.05$ or 0.01 , respectively.
There is little published research describing changes in sugar compositions in root vated $\mathrm{CO}_{2}$. Our results indicate that at the seedling stage, the percentage of fructose and glucose in root exudates increased with an increase in $\mathrm{CO}_{2}$ concentration from 380 to $1200 \mu \mathrm{mol} \cdot \mathrm{mol}^{-1}$. In contrast, at the initial fruiting stage, the percentage of sucrose in root exudates increased with an increase in $\mathrm{CO}_{2}$ concentration from 380 to $1200 \mu \mathrm{mol} \cdot \mathrm{mol}^{-1}$ (Table 3 ). Studies on weeds showed that the percentages of glucose and fructose in root were increased in the growing season from February to July, whereas sucrose was increased after July (Cyr et al., 1990; Wilson et al., 2001). Based on these results, we assume that most photosynthates, which are transported to roots, are present as sucrose and this sucrose hydrolyzed into glucose and fructose for the growth of roots at the seedling stage. As plants mature, sucrose from above ground is accumulated and stored in root. Therefore, it is reasonable that the percentage of glucose in root exudates was directly proportional to $\mathrm{CO}_{2}$ concentration at the seedling stage, whereas the percentage of sucrose was directly proportional to $\mathrm{CO}_{2}$ concentration at the initial fruiting stage.

Although sugars in root exudates released per plant were significantly higher at the initial fruiting stage than that at the seedling stage, the differences in sugars released per gram DW between these two growth stages were not significant. These results indicated that sugars were increased only in as much as exudates when plants are grown with ele- 
root mass increased. The decrease of root exudation with an increase in plant age has been observed on alfalfa [Medicago sativa (Hamlen et al., 1972)], rice [Oryza sativa (Aulakh et al., 2001; Bacilio-Jiménez et al., 2003)], and wheat [Triticum aestivum (Přikryl and Vančura, 1980)]. Four possible explanations for decreased root exudation with plant maturation have been hypothesized (Aulakh et al., 2001; Bacilio-Jiménez et al., 2003; Hamlen et al., 1972): 1) accumulation of high levels of organic compounds in the vicinity of the root, which represses the release of more root exudates; 2) reabsorption of the organic compounds by the root; 3 ) lack of aeration reduces the activity of root; and 4) senescence and death of root over time. Considering the rapid adsorption of root exudates by resin, the concentration of root exudates could not be too high to limit the release of root, and the reabsorption of root exudates was impossible. Additionally, our growing pots were well aerated, so root activity could not be repressed. Therefore, the slight decrease of sugars released per gram DW of root may be caused by the senescence of root from the seedling to initial fruiting stage.

\section{Conclusions}

The optimal reaction conditions for determination of sucrose by analyzing fructose and glucose before and after invertase digestion by a regular HPLC process were studied. This method can be used to identify the soluble sugars in root exudates of cucumber at seedling and initial fruiting stages grown in hydroponic conditions under different $\mathrm{CO}_{2}$ concentrations. Using this method, we determined that glucose was the major sugar in root exudates and constituted $\approx 40 \%$ of the total sugars. The effect of enriched atmospheric $\mathrm{CO}_{2}$ concentrations on the total amount of sugars in the root exudates of cucumber was mainly the result of the increase of root mass.

\section{Literature Cited}

Agüera, E., D. Ruano, P. Cabello, and P. de la Haba. 2006. Impact of atmospheric $\mathrm{CO}_{2}$ on growth, photosynthesis and nitrogen metabolism in cucumber (Cucumis sativus L.) plants. J. Plant Physiol. 163:809-817.

Albersheim, P., D.J. Nevins, P.D. English, and A. Karr. 1968. A method for the analysis of sugars in plant cell wall polysaccharides by gas liquid chromatography. Carbohydr. Res. 5:340-345.

Aulakh, M.S., R. Wassmann, C. Bueno, J. Kreuzwieser, and H. Rennenberg. 2001. Characterization of root exudates at different growth stages of ten rice (Oryza sativa L.) cultivars. Plant Biol. 3:139-148.

Ayari, O., M. Dorais, and A. Gosselin. 2000. Daily variations of photosynthetic efficiency of greenhouse tomato plants during winter and spring. J. Amer. Soc. Hort. Sci. 125:235-241.

Bacilio-Jiménez, M., S. Aguilar-Flores, E. Ventura-Zapata, E. PérezCampos, S. Bouquelet, and E. Zenteno. 2003. Chemical characterization of root exudates from rice (Oryza sativa) and their effects on the chemotactic response of endophytic bacteria. Plant Soil 249:271-277.

Berntson, G.M. and F.A. Bazzaz. 1996. Belowground positive and negative feedbacks on $\mathrm{CO}_{2}$ growth enhancement. Plant Soil 187:119-131.

Cardon, Z.G. 1996. Influence of rhizodeposition under elevated $\mathrm{CO}_{2}$ on plant nutrition and soil organic matter. Plant Soil 187:277-288.

Curl, E.A. and B. Truelove. 1986. The rhizosphere. Springer-Verlag, New York, NY.

Cyr, D.R., J.D. Bewley, and E.B. Dumbroff. 1990. Seasonal dynamics of carbohydrate and nitrogenous components in the roots of perennial weeds. Plant Cell Environ. 13:359-365.

D'Amboise, M., D. Noel, and T. Hanai. 1980. Characterization of bonded-amine packing for liquid chromatography and high sensitivity determination of carbohydrates. Carbohydr. Res. 79:1-10.
Gransee, A. and L. Wittenmayer. 2000. Qualitative and quantitative analysis of water-soluble root exudates in relation to plant species and development. J. Plant Nutr. Soil Sci. 163:381-385.

Haase, S., G. Neumann, A. Kania, Y. Kuzyakov, V. Römheld, and E. Kandeler. 2007. Elevation of atmospheric $\mathrm{CO}_{2}$ and N-nutritional status modify nodulation, nodule-carbon supply, and root exudation of Phaseolus vulgaris L. Soil Biol. Biochem. 39:2208-2221.

Hamlen, R.A., F.L. Lukezic, and J.R. Bloom. 1972. Influence of age and stage of development on the neutral carbohydrate components in root exudates from alfalfa plants grown in a gnotobiotic environment. Can. J. Plant Sci. 52:633-642.

Hanisch, F.G. 1994. Methylation analysis of complex carbohydrates: Overview and critical comments. Biol. Mass Spectrom. 23:309-312.

Heim, A., J. Luster, I. Brunner, B. Frey, and E. Frossard. 2000. Effects of aluminium treatment on norway spruce roots: Aluminium binding forms, element distribution, and release of organic substances. Plant Soil 216:103-116.

Hodge, A., E. Paterson, S.J. Grayston, C.D. Campbell, B.G. Ord, and K. Killham. 1998. Characterisation and microbial utilisation of exudate material from the rhizosphere of Lolium perenne grown under $\mathrm{CO}_{2}$ enrichment. Soil Biol. Biochem. 30:1033-1043.

Kai, M., K. Tamura, M. Yamaguchi, and Y. Ohkura. 1985. Aromatic amidines as fluorogenic reagents for reducing carbohydrates. Anal. Sci. 1:59-63.

Kamilova, F., L.V. Kravchenko, A.I. Shaposhnikov, T. Azarova, N. Makarova, and B. Lugtenberg. 2006. Organic acids, sugars and L-tryptophane in exudates of vegetables growing on stonewool and their effects on activities of rhizosphere bacteria. Mol. Plant Microbe Interact. 19:250-256.

Kato, K., Y. Arima, and H. Hirata. 1997. Effect of exudate released from seeds and seedling roots of common bean (Phaseolus vulgaris L.) on proliferation of Rhizobium sp. (Phaseolus). Soil Sci. Plant Nutr. 43:275-283.

Kimball, B.A. 1983. Carbon dioxide and agricultural yield: An assemblage and analysis of 430 prior observations. Agron. J. 75:779-788.

Kläring, H.P., C. Hauschild, A. Heißner, and B. Bar-Yosef. 2007. Model-based control of $\mathrm{CO}_{2}$ concentration in greenhouses at ambient levels increases cucumber yield. Agr. For. Meteorol. 143:208-216.

Kravchenko, L.V., T.S. Azarova, E.I. Leonova-Erko, A.I. Shaposhnikov, N.M. Makarova, and I.A. Tikhonovich. 2003. Root exudates of tomato plants and their effect on the growth and antifungal activity of Pseudomonas strains. Microbiology 72:37-41.

Kuzyakov, Y. 2002. Review: Factors affecting rhizosphere priming effects. J. Plant Nutr. Soil Sci. 165:382-396.

Lugtenberg, B.J.J., L.V. Kravchenko, and M. Simons. 1999. Tomato seed and root exudate sugars: Composition, utilization by Pseudomonas biocontrol strains and role in rhizosphere colonization. Environ. Microbiol. 1:439-446.

Makino, A. and T. Mae. 1999. Photosynthesis and plant growth at elevated levels of $\mathrm{CO}_{2}$. Plant Cell Physiol. 40:999-1006.

Masuda, R., K. Kaneko, and I. Yamashita. 1996. Sugar and cyclitol determination in vegetables by HPLC using postcolumn fluorescent derivatization. J. Food Sci. 61:1186-1190.

Mikami, H. and Y. Ishida. 1983. Fluorometric detection of carbohydrates with arginine in high-performance liquid chromatography. Shimadzu Rev. 40:249-252.

Montero, C.M., M.C.R. Dodero, D.A.G. Sánchez, and C.G. Barroso. 2004. Analysis of low molecular weight carbohydrates in food and beverages: A review. Chromatographia 59:15-30.

Mortensen, L.M. 1987. Review: $\mathrm{CO}_{2}$ enrichment in greenhouses. Crop responses. Sci. Hort. 33:1-25.

Nelson, J.M. and M.P. Schubert. 1928. Water concentration and the rate of hydrolysis of sucrose by invertase. J. Amer. Chem. Soc. 50:2188-2193.

Peet, M.M. and D.H. Willits. 1987. Greenhouse $\mathrm{CO}_{2}$ enrichment alternatives: Effects of increasing concentration or duration of enrichment on cucumber yields. J. Amer. Soc. Hort. Sci. 129:46-53. 
Přikryl, Z. and V. Vančura. 1980. Root exudates of plant. VI. Wheat root exudation as dependent on growth, concentration gradient of exudates and the presence of bacteria. Plant Soil 57:69-83.

Sánchez-Guerrero, M.C., P. Lorenzo, E. Medrano, N. Castilla, T. Soriano, and A. Baille. 2005. Effect of variable $\mathrm{CO}_{2}$ enrichment on greenhouse production in mild winter climates. Agr. For. Meteorol. 132:244 252.

Schönwitz, R. and H. Ziegler. 1982. Exudation of water-soluble vitamins and of some carbohydrates by intact roots of maize seedlings (Zea mays L.) into a mineral nutrient solution. Zeitschrift für Pflanzenphysiologie 107S:7-14.

Segura, M.L., J.F. Parra, P. Lorenzo, M.C. Sánchez-Guerrero, and E. Medrano. 2001. The effects of $\mathrm{CO}_{2}$ enrichment on cucumber growth under greenhouse conditions. Acta Hort. 559:217-222.

Sharma, R., Y.S. Rajput, Poonam, G. Dogra, and S.K. Tomar. 2009. Estimation of sugars in milk by HPLC and its application in detection of adulteration of milk with soymilk. Intl. J. Dairy Technol. 62:514519.

Sharma, U., P. Bhandari, N. Kumar, and B. Singh. 2010. Simultaneous determination of ten sugars in Tinospora cordifolia by ultrasonic assisted extraction and LC-ELSD. Chromatographia 71:633-638.

Soga, T., Y. Inoue, and K. Yamaguchi. 1992. Determination of carbohydrates by hydrophilic interaction chromatography with pulsed amperometric detection using postcolumn $\mathrm{pH}$ adjustment. J. Chromatography 625:151-155.
Spackman, V.M.T. and A.H. Cobb. 2002. An enzyme-based method for the rapid determination of sucrose, glucose and fructose in sugar beet roots and the effects of impact damage and postharvest storage in clamps. J. Sci. Food Agr. 82:80-86.

Sweeley, C.C., R. Bentley, M. Makita, and W.W. Wells. 1963. Gasliquid chromatography of trimethylsilyl derivatives of sugars and related substances. J. Amer. Chem. Soc. 85:2497-2507.

Tang, C.S. and C.C. Young. 1982. Collection and identification of allelopathic compounds from the undisturbed root system of bigalta limpograss (Hemarthria altissima). Plant Physiol. 69:155-160.

Tawaraya, K., K. Sasai, and T. Wagatsuma. 1994. Effect of phosphorus application on the contents of amino acids and reducing sugars in the rhizosphere and VA mycorrhizal infection of white clover. Soil Sci. Plant Nutr. 40:539-543.

Vančura, V. and A. Hovadík. 1965. Root exudates of plants. II. Composition of root exudates of some vegetables. Plant Soil 22:21-32.

Wei, M., Y. Xing, X. Wang, and H. Ma. 2002. $\mathrm{CO}_{2}$ environment in solar greenhouse in northern China and effects of $\mathrm{CO}_{2}$ enrichment on photosynthetic rate and dry matter production of cucumber. Acta Hort. 633:115-120.

Wilson, R.G., S.D. Kachman, and A.R. Martin. 2001. Seasonal changes in glucose, fructose, sucrose, and fructans in the roots of dandelion. Weed Sci. 49:150-155.

Yamazaki, K. 1982. Nutrient solution culture. Pak-kyo Co., Tokyo, Japan. 